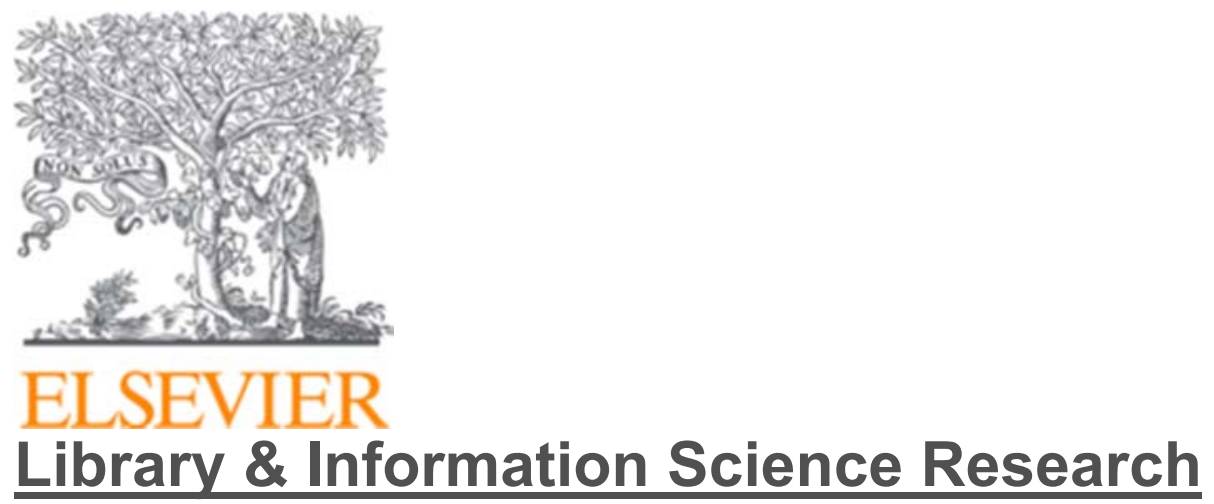

Volume 41, Issue 3, July 2019, 100969



\title{
Effect of perceived ease of use on librarians' e-skills: Basis for library technology acceptance intention
}

Author links open overlay panelRolandlzuagbe ${ }^{a}$

Nurudeen Ademolalbrahimb

Lilofa OsamienfaOgiamienc

Olajumoke RebeccaOlawoyin ${ }^{a}$

Nwanne MaryNwokeoma ${ }^{a}$

Promise Ifeomalloa

OdaroOsayandea

Show more

https://doi.org/10.1016/j.lisr.2019.100969Get rights and content

\section{Highlights}

e-Skills independently facilitated librarians' intention towards library technology acceptance. 
Perceived ease of use (PEOU) and e-Skills are positively and significantly correlated toward library technology acceptance intention.

PEOU is a significant moderator of e-Skills vis-à-vis library technology acceptance intention.

e-Skills is a stronger factor of technology acceptance intention among than PEOU.

\section{Abstract}

Despite the widespread application of technology in the 21st century, making informed decisions regarding its acceptance in organisations is a function of several factors, particularly in developing countries, due to factors such as rising cost of the information technology infrastructure and low technological exposure. A model that incorporated perceived ease of use (PEOU) and eSkills to examine librarians' intention for actual library technology acceptance was tested. The correlational research design, along with a multistage sampling procedure, was applied to select samples to reduce the sample to a manageable proportion. Professional librarians and library officers in four university libraries provided the data for the study. Results showed that e-Skill is the model's strongest determinant of technology acceptance intention among librarians. Also, PEOU will significantly moderate librarians' intention towards library technology acceptance when e-Skills are insufficient. From these outcomes, the understanding of the determinants of behavioural intention captured in the Technology Acceptance Model (TAM) and the Unified Theory of Acceptance and Use of Technology (UTAT) is extended and refined.

Roland Izuagbe, is a serials librarian with Librarian II designation in Center for Learning Resources, Covenant University, Ota, Nigeria. Roland holds a Bachelor of Science (BSc) in library and information science from Ambrose Alli University (AAU) Ekpoma, and a master degree in library and information studies (MLIS) from the University of Ibadan, Ibadan. He has published in The Journal of 
Academic Librarianship (JACALIB), International Journal of Disaster Risk Reduction (IJDRR), Library Review (Now, Global Knowledge, Memory and Communication), Journal of Cases on Information Technology (JCIT), Journal of Information Science Theory and Practice (JISTaP), among others. His research interests include information and communication technology (ICT), information systems acceptance/adoption, electronic information resources, disaster management in libraries, social media use in libraries and organisational science.

Nurudeen Ademola Ibrahim, is a librarian at the University of Ibadan. He holds a BSc in physics and a masters degree in library and information studies (MLIS) from the University of Ibadan, Ibadan. He is currently at the postgraduate unit of the Faculty of Law, University of Ibadan. His research interests include application of ICT to library services, information product marketing and services, conservation and preservation of library and information resources and emerging trends in LIS.

Lilofa Osamienfa Ogiamien, is a librarian II at Benson Idahosa University, Benin City. She holds a BSc in Business Management and a masters in library and information science (MLIS) from Benson Idahosa University, Benin City and the University of Ibadan, Ibadan respectively. Lilofa has published in The Journal of Academic Librarianship (JACALIB), Open Access Library (OALib), Journal of Information and Knowledge Management (JIKM) and Nigerian Journal of Library and Archival Information.

Olajumoke Rebecca Olawoyin is a doctoral student in the department of information resource management, Babcock University llishan-Remo, Ogun State, Nigeria where she obtained her master's degree in information resource management. Olawoyin is presently a Librarian II in the Centre for Learning Resources (Covenant University Library). Her research interests include information behaviour, collection development, preservation of information resources, service quality of information personnel, team building and information policy. She has published in The Journal of Academic Librarianship (JACALIB), Journal of Cases on Information Technology (JCIT), Library Philosophy and Practice, Jewel Journal of Librarianship.

Nwanne Mary Nwokeoma is a readers' services librarian in the Centre for Learning Resources, Covenant University. She holds a bachelors degree (BLIS) in library archival and information studies and a master's degree (MIS) in information science both from the University of Ibadan. Currently, her research interests include information literacy for youth, application of technology to library services and users' access and satisfaction. She has published in Journal of Cases on Information Technology (JCIT), International Journal of Information and Communication Technology (ICT), International Journal of Library Science, Association of College and Research Libraries, Information Technologist, among others.

Promise Ifeoma Ilo is the Director, Centre for Learning Resources, Covenant University Ota, Nigeria. Dr. llo obtained a PhD in library and information science from the University of Nigeria Nsukka (2017). She has published in International Journal of Disaster Risk Reduction (IJDRR), Disaster Prevention and Management: An International Journal, New Review of Academic Librarianship, Evidence Based Library and Information Practice, Global Review of Library and Information Science, etc. Her research interests include disaster management in libraries, library 
users education, information and communication in libraries, and health information awareness among rural dwellers.

Odaro Osayande is a doctoral student in the Department of Information Studies, University of KwaZulu-Natal, Pietermanitzburg, Campus, South Africa. Odaro is also a librarian at the Centre for Learning Resources (University Library), Covenant University, Canaan Land, Ota- Ogun State, Nigeria. He holds a masters degree in library and information studies (MLIS) from the University of Ibadan, Ibadan. He has published in Chinese Librarianship: An International Electronic Journal, Annals of Library and Information Studies, Library Philosophy and Practice, and The International Journal of Communication and Health. His research interests include library security, academic libraries, user education and gray literature.

View full text

(c) 2019 Elsevier Inc. All rights reserved.

We use cookies to help provide and enhance our service and tailor content and ads. By continuing you agree to theuse of cookies. Copyright (C) 2019 Elsevier B.V. or its licensors or contributors. ScienceDirect ${ }^{\circledR}$ is a registered trademark of Elsevier B.V. 